\title{
Prediction of Consolidation Characteristics from Index Properties
}

\author{
Kok Shien $\mathrm{Ng}^{1 *}$, Yee Ming Chew ${ }^{2}$ and Nur Izzati Ahmad Lazim ${ }^{3}$ \\ ${ }^{1}$ Faculty of Civil Engineering, UiTM Pulau Pinang, 13500 Permatang Pauh, Pulau Pinang \\ ${ }^{2}$ Department of Mathematical Sciences and Computer, UiTM Pulau Pinang, 13500 Permatang Pauh, \\ Pulau Pinang \\ ${ }^{3}$ Faculty of Civil Engineering, UiTM Pulau Pinang, 13500 Permatang Pauh, Pulau Pinang
}

\begin{abstract}
Compression index and coefficient of consolidation are two most important parameters in obtaining the consolidation characteristics of cohesive soil. Considerable time and effort are required to obtain these parameters from the oedometer test. Therefore, this study aims to correlate these two parameters with the index properties. Five remoulded samples are tested for their physical properties as well as their consolidation characteristics. The results show good relationship was obtained for the liquid limit and the compression index while the coefficient of consolidation is best correlated with the plastic limit. Multiple regression analysis was performed to improve the prediction. Liquid limit is best coupled with specific gravity to estimate the compression index while plastic limit and plastic index can be used to best predict the coefficient of consolidation.
\end{abstract}

\section{Introduction}

Geotechnical investigation is required before constructing any structure for a safe and economic design which include surface and subsurface exploration of the site. Lack of knowledge about the compressibility of soil that is important in the design of the building and infrastructure may lead to the construction fault which is costly in materials and efforts. Compressibility of the soil is its capacity to decrease in volume under pressure and is indicated by soil characteristic likes compression index $\left(\mathrm{C}_{\mathrm{c}}\right)$ and coefficient of consolidation $\left(\mathrm{C}_{\mathrm{v}}\right)$. Compression index is used for settlement estimation while coefficient of consolidation is used to predict the time required for a given amount of compression to take place.

The prediction of magnitude and the rate of consolidation settlements in consolidation theory is important for serviceability of structure founded on a compressible soil layer. The consolidation characteristics can be obtained by conducting a one-dimensional consolidation test using oedometer apparatus. However, the determination of coefficient of consolidation and compression index of soil from oedometer test require considerable time

\footnotetext{
* Corresponding author: ngkokshien@ppinang.uitm.edu.my
} 
and effort. Therefore, several attempts have been made to predict the value of compression index and coefficient of consolidation from empirical correlation linked with the index properties which are relatively easier and faster [1-9]. Skempton [1] is the first to correlate the compression index of remoulded clay with index properties. Table 1 shows different correlations to predict compression index reported in the literature. Comparing to compression index prediction, there are limited studies that have been made in the past to predict the coefficient of consolidation. Table 2 shows various approximations to predict $\mathrm{C}_{\mathrm{v}}$.

Table 1. Compression index equation by various authors

\begin{tabular}{ccc}
\hline References & Equations & Samples \\
\hline $\begin{array}{c}\text { Skempton } \\
\text { [1] }\end{array}$ & $\mathrm{C}_{\mathrm{c}}=0.007$ (LL-10) & Remoulded Clays \\
$\begin{array}{c}\text { Terzaghi and } \\
\text { Peck [2] }\end{array}$ & $\mathrm{C}_{\mathrm{c}}=0.009(\mathrm{LL}-10)$ & $\begin{array}{c}\text { Normally } \\
\text { consolidated, } \\
\text { Moderate sensitivity }\end{array}$ \\
\hline $\begin{array}{c}\text { Wroth and } \\
\text { Wood [3] }\end{array}$ & $\mathrm{C}_{\mathrm{c}}=0.0135 \mathrm{PI}$ & $\begin{array}{c}\text { All remoulded, } \\
\text { normally } \\
\text { consolidated clays }\end{array}$ \\
\hline $\begin{array}{c}\text { Vinod and } \\
\text { Bindu [4] }\end{array}$ & $\mathrm{C}_{\mathrm{c}}=0.0055(\mathrm{LL}-$ & High plastic clays \\
\hline $\begin{array}{c}\text { Widodo and } \\
\text { Ibrahim [5] }\end{array}$ & $\mathrm{C}_{\mathrm{c}}=0.01706(\mathrm{LL}-1.30)$ & Soft Clays \\
\hline LL= Liquid limit, $\mathrm{G}_{\mathrm{s}}=$ Specific gravity, PI = Plastic index
\end{tabular}

Table 2. Coefficient of consolidation approximations by various authors

\begin{tabular}{|c|c|c|}
\hline References & Equation & Samples \\
\hline Sridharan and Nagaraj [6] & $\mathrm{C}_{\mathrm{v}}=3 /\left(100 \mathrm{IS}^{3.54}\right) \quad\left(\mathrm{m}^{2} / \mathrm{s}\right)$ & Remoulded soils \\
\hline Solanki and Desai [7] & $\mathrm{C}_{\mathrm{v}}=7.7525 \mathrm{PI}^{-3.1021}\left(\mathrm{~cm}^{2} / \mathrm{s}\right)$ & $\begin{array}{c}\text { Normally } \\
\text { consolidated soils }\end{array}$ \\
\hline Soibam et al. [8] & $\mathrm{C}_{\mathrm{v}}=4 \mathrm{X} 10^{-7}-4 \times 10^{9} \mathrm{LL}\left(\mathrm{m}^{2} / \mathrm{s}\right)$ & Soft clays \\
\hline Jadhav [9] & $\begin{array}{c}\mathrm{C}_{\mathrm{v}}=128.7 / 3.54 \mathrm{IS}+0.0002 \\
\left(\mathrm{~cm}^{2} / \mathrm{s}\right)\end{array}$ & $\begin{array}{l}\text { Clays with wide } \\
\text { range of liquid limit }\end{array}$ \\
\hline
\end{tabular}

\section{Materials and methods}

Five cohesive soil samples were selected in the present study and have been evaluated for their physical properties. The index properties tests were carried out according to BS:1997part 2, 1990. The LL test was carried out with fall cone test while plastic limit, PL test was carried with rolling thread method. The summary of the soil properties is shown in Table 3. The LL of the five samples ranges from $29 \%$ to $46 \%$ with PI ranges from $8-18$. The onedimensional consolidation tests for five remoulded soil were performed accordance to BS1377: Part 5: 1990 with oedometer equipment. The samples were hand remoulded at their respective liquid limit. The samples were loaded to $800 \mathrm{kPA}$ with four increment stage. From the oedometer data, the void ratio curve on a semi-log has been plotted where the tangent of linear portion of the pressure is a value of compression index, $\mathrm{C}_{\mathrm{c}}$. The coefficient of consolidation, $\mathrm{C}_{\mathrm{v}}$ was calculated using Taylor's Method obtained from the plot of square root time-deformation curve. Due to small different in $\mathrm{C}_{\mathrm{v}}$ values for each loading stage, the value of $\mathrm{C}_{\mathrm{v}}$ presented here is obtained from loading at $200 \mathrm{kPa}$. Index 
properties are correlated with $\mathrm{C}_{\mathrm{c}}$ and $\mathrm{C}_{\mathrm{v}}$ to determine the best correlated parameter using simple linear regression. In addition, multiple regression analysis was conducted to determine two most controlling variables in predicting the $\mathrm{C}_{\mathrm{c}}$ and $\mathrm{C}_{\mathrm{v}}$.

Table 3. Summary of Soil Properties

\begin{tabular}{|c|c|c|c|c|c|c|}
\hline \multicolumn{2}{|l|}{ Sample no. } & 1 & 2 & 3 & 4 & 5 \\
\hline \multicolumn{2}{|c|}{ Specific gravity, $\mathrm{G}_{\mathrm{s}}\left(\mathrm{mg} / \mathrm{m}^{3}\right)$} & 2.56 & 2.55 & 2.57 & 2.58 & 2.52 \\
\hline \multirow{3}{*}{$\begin{array}{l}\text { Atterberg } \\
\text { Limits (\%) }\end{array}$} & Liquid Limit, LL & 35 & 38 & 29 & 46 & 36 \\
\hline & Plastic Limit, PL & 22 & 24 & 21 & 28 & 24 \\
\hline & $\begin{array}{l}\text { Plasticity index, } \\
\text { PI }\end{array}$ & 13 & 14 & 8 & 18 & 12 \\
\hline \multirow{3}{*}{$\begin{array}{c}\text { Particle Size } \\
\text { Distribution } \\
(\%)\end{array}$} & Clay & 12.69 & 12.24 & 5.94 & 16.76 & 13.96 \\
\hline & Silt & 51.49 & 55.67 & 61.81 & 52.40 & 54.45 \\
\hline & Sand & 35.82 & 32.09 & 32.25 & 30.84 & 31.59 \\
\hline \multicolumn{2}{|c|}{ Classification of soil } & CIS & CI & $\mathrm{CL}$ & MI & CI \\
\hline
\end{tabular}

* CIS: Sandy Clay of Intermediate Plasticity; CI: Clay of Intermediate Plasticity; CL: Clay of Low Plasticity; MI: Silt of Intermediate Plasticity

\section{Result of consolidation characteristics}

The results of oedometer test for five tested samples in terms of compression index and coefficient of consolidation are shown in Table 4. The $C_{c}$ ranges from 0.19 to 0.28 while $C_{v}$ ranges from 0.3 to 0.48 . Table 4 . Four index properties are used to correlate with the LL and the results is shown in Fig. 1. All of the results show the increase of $\mathrm{C}_{\mathrm{c}}$ with the increase of index properties except the fine content, F\%. From the single regression analysis, the liquid limit is best correlated with the compression index:

$$
\mathrm{C}_{\mathrm{c}}=0.0062 \mathrm{LL}+0.0165
$$

Similar findings are obtained by other researchers as can be seen in Table 1. Modest relationships are obtained for fine particles, plastic index and plastic limit. Skempton's equation [1] was used to predict the results, and the differences are $27 \%, 2 \%, 30 \%, 10 \%$, and $24 \%$ respectively compared with sample no. 1 to 5 .

Table 4. Oedometer results

\begin{tabular}{cccccc}
\hline Sample & $\mathbf{1}$ & $\mathbf{2}$ & $\mathbf{3}$ & $\mathbf{4}$ & $\mathbf{5}$ \\
\hline $\mathbf{C}_{\mathbf{c}}$ & 0.24 & 0.2 & 0.19 & 0.28 & 0.25 \\
\hline $\mathbf{C}_{\mathbf{v}}\left(\mathbf{m}^{2} / \mathbf{y r}\right)$ & 0.36 & 0.35 & 0.48 & 0.3 & 0.4 \\
\hline
\end{tabular}

Subsequent multiple regression analysis shows that the correlation of $L L$ and $C_{c}$ can be further improved with the addition of another index property which is the specific gravity, $\mathrm{G}_{\mathrm{s}}$ as shown in Eq. (2) in which the coefficient of determination, $\mathrm{R}^{2}$ is 0.998 .

$$
\mathrm{C}_{\mathrm{c}}=0.27 \mathrm{GS}-0.005 \mathrm{LL}-0.26
$$



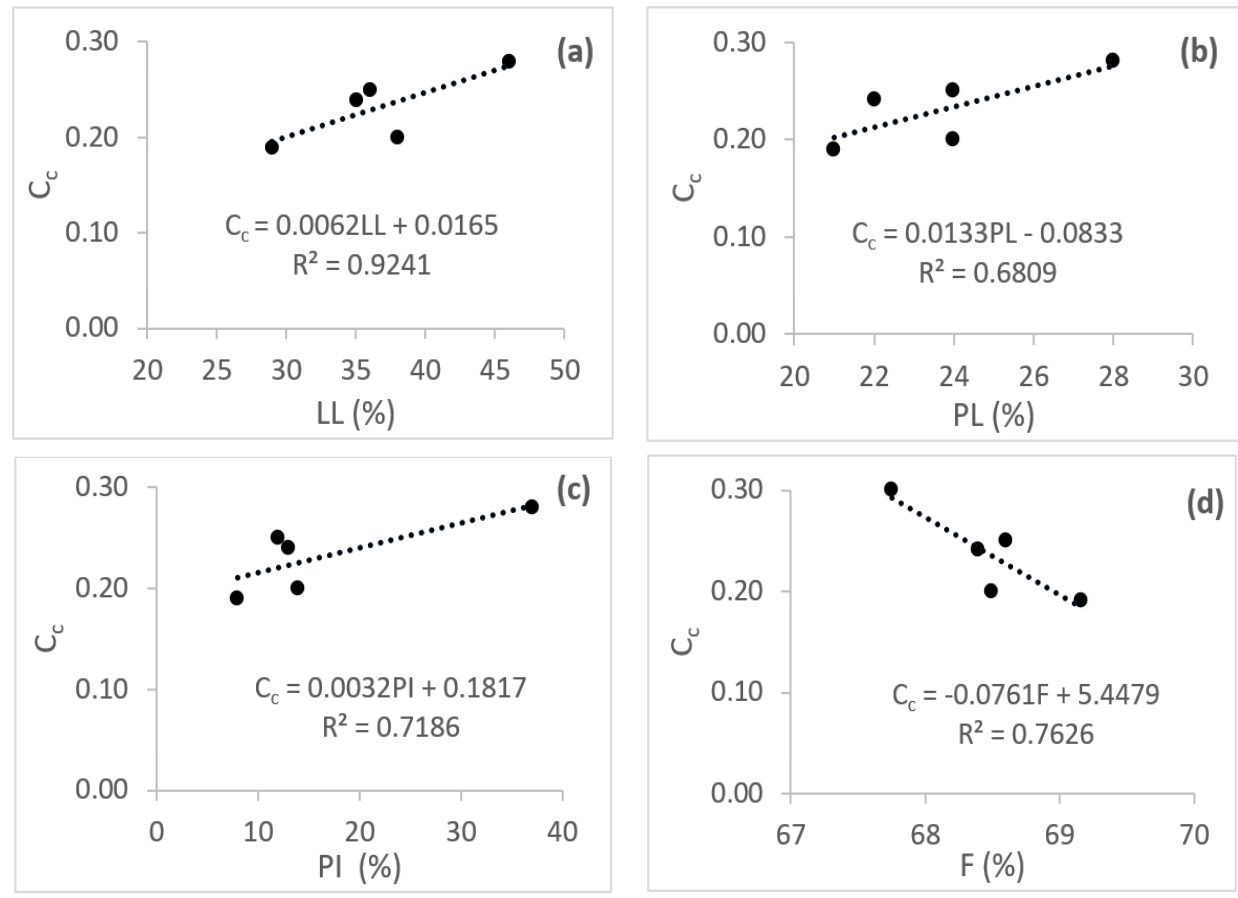

Fig. 1. a) LL vs $C_{c}$, b) PL vs $C_{c}$, c) PI vs $C_{c}$, and d) F vs $C_{c}$

Figure 2 shows the $\mathrm{C}_{\mathrm{v}}$ value is best correlated with the PI. The relationship of $\mathrm{C}_{\mathrm{v}}$ and PI is shown in Eq. (3). Solanki and Desai [7] reported the similar finding. The correlation with $\mathrm{F} \%$ is not satisfactory with low degree of relationship. Generally, $\mathrm{C}_{\mathrm{v}}$ descreases with the increase of the index property. Through multiple regression analysis, LL and PI can be used to best estimate the coefficient of consolidation as shown in Eq. (4) with $R^{2}=0.994$.

$$
\begin{array}{rr}
\mathrm{C}_{\mathrm{v}}=0.6155-0.0183 \mathrm{PI} & \text { in } \mathrm{m}^{2} / \mathrm{yr} \\
\mathrm{C}_{\mathrm{v}}=0.451+0.011 \mathrm{LL}-0.0367 \mathrm{PI} & \text { in } \mathrm{m}^{2} / \mathrm{yr}
\end{array}
$$

\section{Conclusions}

Five cohesive samples were remoulded and subjected to one dimensional consolidation test. The compression index was found to be best correlated with the liquid limit while and the coefficient of consolidation was best correlated with the plastic index. Further multiple regression analysis showed that the specific gravity and liquid limit are best coupled in predicting the compression index. While best correlation was obtained using liquid limit and plastic index to estimate the coefficient of consolidation. 

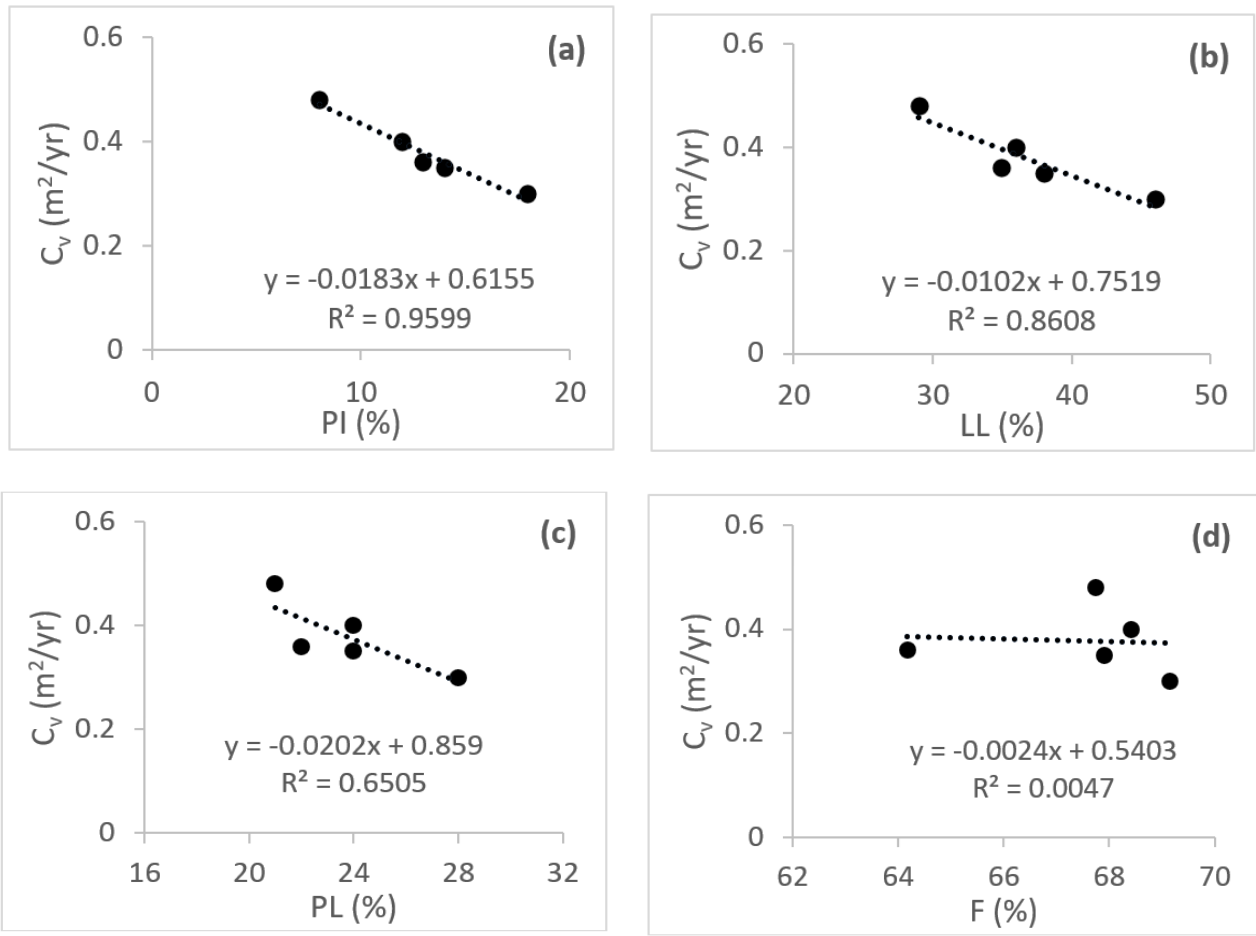

Fig. 2. a) $L L$ vs $C_{v}$, b) $P L$ vs $C_{v}$, c) $P I$ vs $C_{v}$, and d) $F$ vs $C_{v}$

\section{References}

1. A. W. Skempton, Q. J. Geol. Soc. London, 100, 119-135 (1944)

2. K. Terzaghi, R. B. Peck, Soil mechanics in engineering practice (2nd Ed., John Wiley and Sons, Inc., New York, 1967)

3. C. P. Wroth, D. M. Wood, Can. Geotech. J., 15,137-145 (1978)

4. P. Vinod, J. Bindu, Indian Geotech. J., 174-180 (2010)

5. S. Widodo, A. Ibrahim, Int. J. Eng. Research and Appl., 2, 2232-2236 (2012)

6. A. Sridharan, H. B. Nagaraj, Geotech. Testing J., 27(5), 469-474 (2004)

7. C. H. Solanki, M. D. Desai, J. Eng. Technol., 12-15 (2008)

8. P. D. Soibam, R. D. Konsam, D. S. V. Prasad, G. V. R. Prasada Raju, Int. J. Eng. Research and Development, 11(5), 57-63 (2015).

9. P. G. Jadhav, Int. J. Adv. Research in Sci. Eng., 5(12), 299-309 (2016) 